\title{
'Blaschkoid' giant wart in immunocompetent patient
}

\author{
Tiago Mestre, Gabriela Marques Pinto
}

Department of Dermatology, Hospital Curry Cabral, Lisbon, Portugal

\section{Correspondence to Dr Tiago Mestre, tiago.g.mestre@gmail.com}

Accepted 29 March 2014
CrossMark

To cite: Mestre T, Marques Pinto G. BMJ Case Rep Published online: [please include Day Month Year] doi:10.1136/bcr-2014204787

\section{DESCRIPTION}

The human papillomavirus (HPV) can infect the skin and mucous membranes. Common warts, filiform warts, epidermodysplasia verruciformis, mosaic warts and plantar warts represent clinical manifestations of infection with HPV. Giant warts in the hands are very rare in immunocompetent adults and sometimes by their extension or atypical location represent a diagnostic and therapeutic challenge. The giant tumours caused by HPV are more common in the anogenital region where they are known as Buschke-Loewenstein tumours. No risk factor has yet been identified for giant warts in immunocompetent patients.

The authors report this rare case of a giant wart with a linear configuration (figure 1) in an immunocompetent 40-year-old adult in whom clinical presentation resembled a verrucous epidermal naevus. Other differential diagnoses such as cutaneous adnexal neoplasms and squamous cell carcinoma have to be thought. HPV lesions of long duration and subjected to various treatments tend to lose their histology (figure 2) and most of the times HPV DNA cannot be detected by PCR in the histological specimen ${ }^{1}$ (as was the case). This fact, associated with the nodular and hyperkeratotic nature of these lesions may explain the poor response to various therapies performed before and a not so marked response to imiquimod. The patient was initially treated with imiquimod during

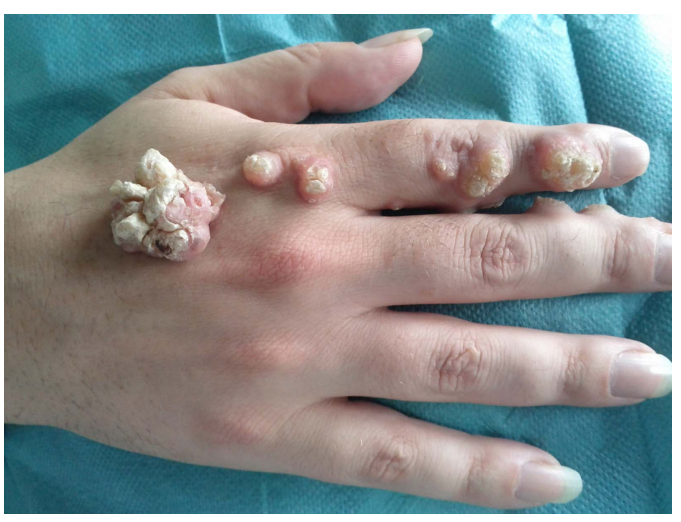

Figure 1 Long-standing verrucous nodules, with linear distribution, simulating Blaschko's lines.

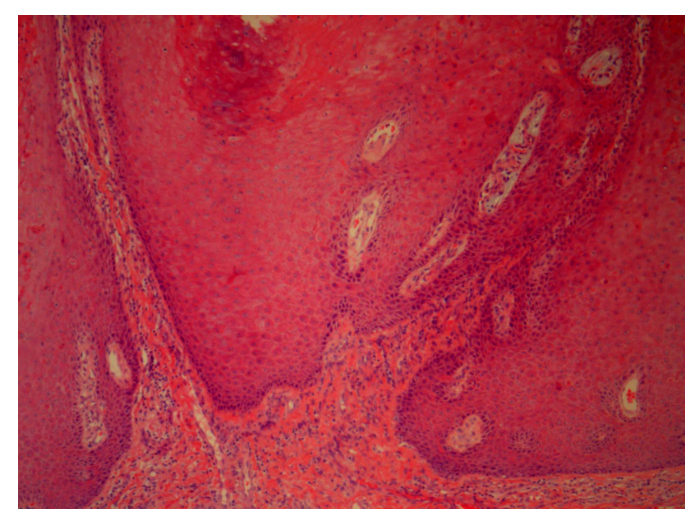

Figure 2 Histopathological examination: hyperplasia of all layers of the epidermis with areas of parakeratosis, papillomatosis and presence of koilocytes.

12 weeks to reduce the size of the lesions and subsequently serial excision of the resistant nodes was carried out.

\section{Learning points}

- Giant warts in immunocompetent patients are very rare. Causes of immunosuppression should be excluded.

- Histopathological examination is important to exclude other important clinical diagnosis.

- Early diagnosis and treatment is important to achieve a better cosmetic and functional result.

Contributors TM was involved in the conception, design, analysis and interpretation of the data, drafting of the manuscript, and final approval. GMP was involved in the critical revision of the manuscript and final approval.

\section{Competing interests None.}

Patient consent Obtained.

Provenance and peer review Not commissioned; externally peer reviewed.

\section{REFERENCE}

1 Ergün SS, Su O, Büyükbabaný N. Giant verruca vulgaris. Dermatol Surg 2004;30:459-62. 
Copyright 2014 BMJ Publishing Group. All rights reserved. For permission to reuse any of this content visit http://group.bmj.com/group/rights-licensing/permissions.

BMJ Case Report Fellows may re-use this article for personal use and teaching without any further permission.

Become a Fellow of BMJ Case Reports today and you can:

- Submit as many cases as you like

- Enjoy fast sympathetic peer review and rapid publication of accepted articles

- Access all the published articles

- Re-use any of the published material for personal use and teaching without further permission

For information on Institutional Fellowships contact consortiasales@bmjgroup.com

Visit casereports.bmj.com for more articles like this and to become a Fellow 